\title{
Investigation and Analysis of Buildings Damaged during the September 2007 Sumatra, Indonesia Earthquakes
}

\author{
Maidiawati*1 $^{1}$ and Yasushi Sanada ${ }^{2}$ \\ ${ }^{1}$ Graduate Student, Graduate School of Engineering, Toyohashi University of Technology, Japan \\ ${ }^{2}$ Associate Professor, Faculty of Engineering, Toyohashi University of Technology, Japan
}

\begin{abstract}
Earthquakes occurring on September $12\left(8.4 \mathrm{M}_{\mathrm{L}}\right)$ and $13\left(7.9 \mathrm{M}_{\mathrm{L}}\right), 2007$, in South and West Sumatra, Indonesia, respectively, damaged many buildings. This paper reports investigation results on damaged buildings in and around Padang, West Sumatra, and discusses the seismic performance of two reinforced concrete (RC) frame structures with unreinforced masonry (URM) brick walls.

Observations revealed that several RC structures with URM walls suffered severe damage such as shear failure of columns, buckling of column longitudinal reinforcements, and collapse of brick walls. In confined and simple URM structures, damage mainly to brick walls was observed. On the contrary, timber structures performed relatively well during the earthquakes.

Two calculations were performed - one with and one without infill walls, focusing on two three-story collapsed and surviving RC buildings in Padang. A distinct difference was identified between the seismic performance of the two buildings when considering infill walls. Therefore, these samples of earthquakedamaged buildings verify that nonstructural infill walls can significantly contribute to the seismic performance of this type of structure.
\end{abstract}

Keywords: post-earthquake investigation; reinforced concrete; seismic performance evaluation; the 2007 Sumatra earthquake; unreinforced masonry

\section{Introduction}

Sumatra Island, Indonesia is located close to a major earthquake fault line, where destructive earthquakes have occurred during the last three years. The greatest at 9.1 on the Richter scale $\left(\mathrm{M}_{\mathrm{L}}\right)$, which caused a huge tsunami, occurred at Aceh, northern Sumatra on December 26, 2004. Then, a magnitude $8.6 \mathrm{M}_{\mathrm{L}}$ earthquake struck Nias Island in North Sumatra province on March 28, 2005. In 2007, there were three earthquakes of magnitude $6.4 \mathrm{M}_{\mathrm{L}}$ and greater around Padang, the capital of West Sumatra province: a 6.4 $\mathrm{M}_{\mathrm{L}}$ quake struck Bukit Tinggi about $49 \mathrm{~km}$ north of Padang on March 6, 2007; a $8.4 \mathrm{M}_{\mathrm{L}}$ quake occurred offshore of Bengkulu in southern Sumatra about 410 $\mathrm{km}$ from Padang; and the following 7.9 $\mathrm{M}_{\mathrm{L}}$ quake occurred near Kepulauan Mentawai, an offshore area about $190 \mathrm{~km}$ southeast of Padang.

\footnotetext{
*Contact Author: Maidiawati, Graduate Student,

Graduate School of Engineering, Toyohashi University of Technology, 1-1 Hibarigaoka, Tempakucho,

Toyohashi, 441-8580 Japan

Tel: +81-532-44-6848 Fax: +81-532-44-6848

E-mail: maidiawati@yahoo.com

(Received April 8, 2008 ; accepted July 18, 2008)
}

Padang suffered moderate damage mainly due to the 2007 earthquakes of magnitudes 8.4 and $7.9 \mathrm{M}_{\mathrm{L}}$. The authors investigated damage to buildings in Padang and nearby areas from October 15 to 19,2007 to obtain specific data. The reconnaissance was carried out in collaboration with Dr. Yukiko Nakamura, Niigata University, Japan and Dr. Jafril Tanjung, Andalas University, Indonesia.

This paper reports the results of our on-site investigation. Moreover, it discusses the seismic performance of reinforced concrete (RC) buildings with unreinforced masonry (URM) brick walls based on brief analyses as well as observed damage.

\section{Brief Description of the 2007 Earthquakes of Magnitudes 8.4 and 7.9 $\mathrm{M}_{\mathrm{L}}$}

According to information provided by the U.S. Geological Survey (USGS) ${ }^{1)}$, the epicenters of the magnitude 8.4 and $7.9 \mathrm{M}_{\mathrm{L}}$ earthquakes, occurring on September 12, at 06:10:26 PM and September 13, at 06:49:04 AM local time in Indonesia, were located at $4.520^{\circ} \mathrm{S}, 101.374^{\circ} \mathrm{E}$, at a depth of $34 \mathrm{~km}$, and $2.506^{\circ} \mathrm{S}$, $100.906^{\circ} \mathrm{E}$, at a depth of $30 \mathrm{~km}$, respectively, as shown in Fig. 1.

Based on data reported by the National Disaster Management Coordinating Board of Indonesia 


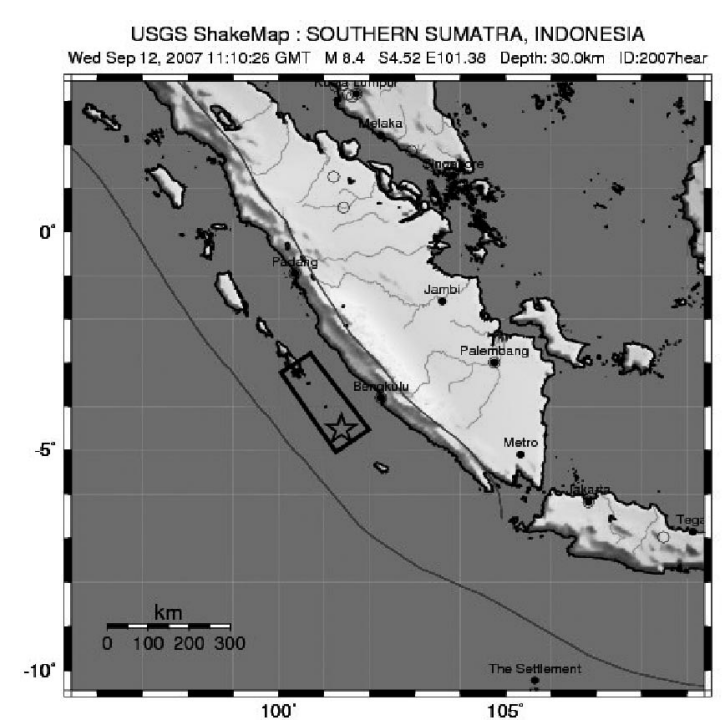

(a) $8.4 \mathrm{M}_{\mathrm{L}}$ Earthquake

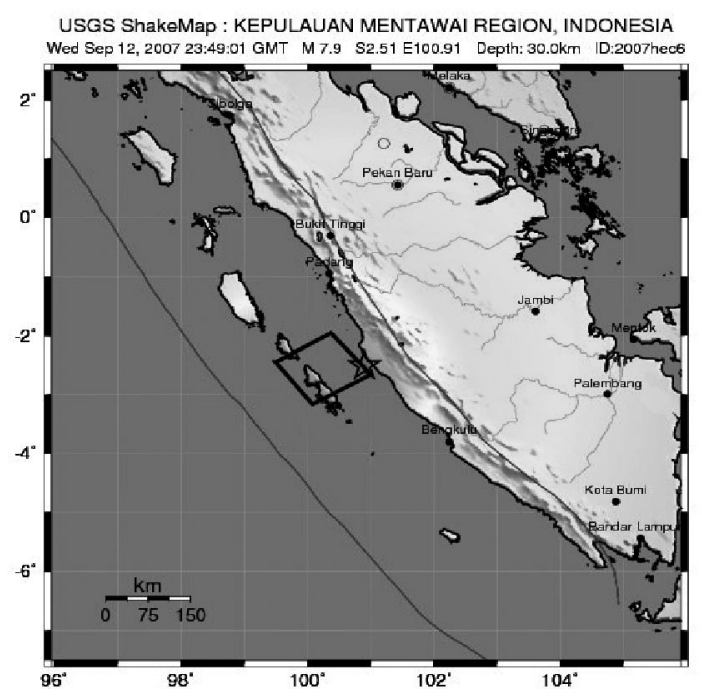

(b) $7.9 \mathrm{M}_{\mathrm{L}}$ Earthquake

Source: USGS ${ }^{1)}$

Fig.1. Epicenters of 8.4 $\mathrm{M}_{\mathrm{L}}$ and 7.9 $\mathrm{M}_{\mathrm{L}}$ Earthquakes

(BAKORNAS) $^{2)}$, the earthquakes killed 25 persons, seriously injured 41 , and lightly injured 51 . The earthquakes collapsed two engineering buildings in Padang, and many other buildings were damaged in Bengkulu and West Sumatra. In Bengkulu, 7,050 residences collapsed, 10,522 were heavily damaged, and 35,041 were lightly damaged. In West Sumatra, $10,915,10,505$, and 14,392 residences suffered heavy, medium, and light damage, respectively. In particular, Pesisir Selatan, a coastal area, and Kepulauan Mentawai suffered the most severe damage.

\section{Typical Building Damage in the Investigated Area}

The first stage of the investigation was a preliminary damage survey in Padang city and nearby areas along the coast, as shown in Fig.2., which was carried out to observe typical buildings and their damage.

Most of the buildings can be classified into four

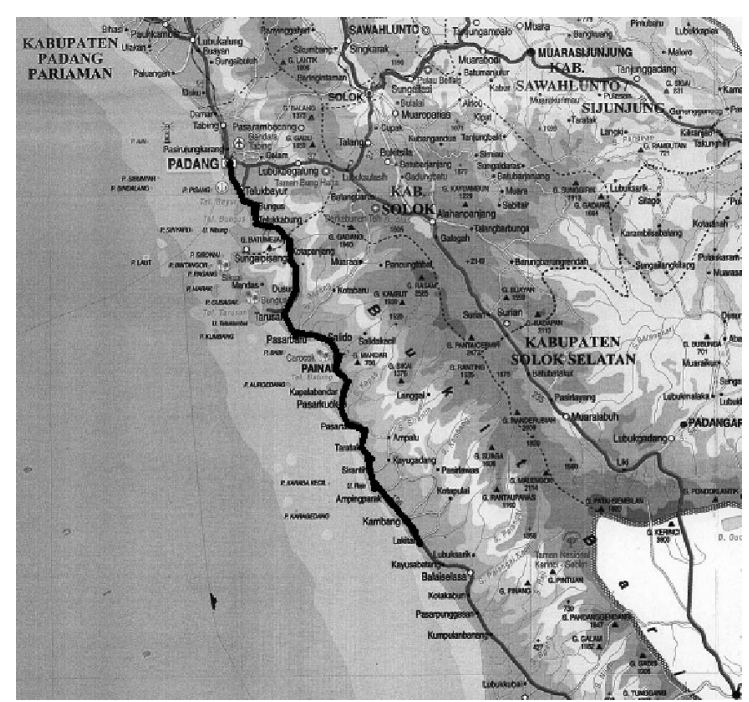

(a) Survey Route Map

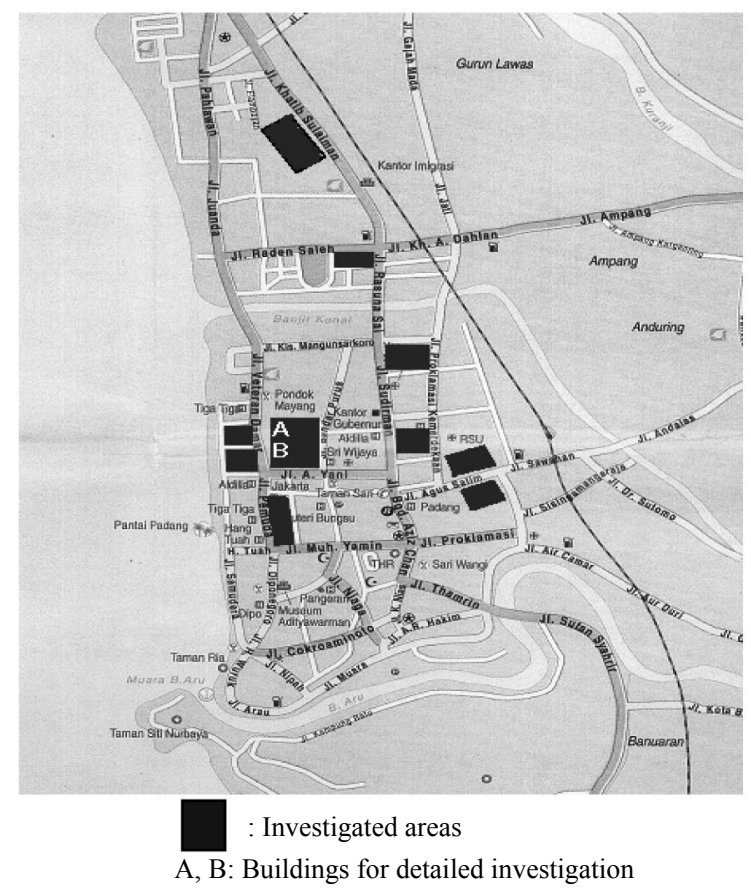

(b) Padang City Map

Fig.2. Investigated Areas

types.

1. RC-frame + URM: RC moment-resisting frame structure with URM brick walls.

2. RC-tie + URM: URM brick structure confined with $\mathrm{RC}$ ties.

3. URM: URM brick structure.

4. TIM: Timber structure.

The former three types were popular in the city. On the other hand, the latter three were common in provincial areas.

The RC-frame + URM type is commonly constructed for buildings of more than two stories. Concrete slabs or tile roofs are conventionally used for roofing. Several examples of typical damage were observed for this type: total collapse of buildings as 

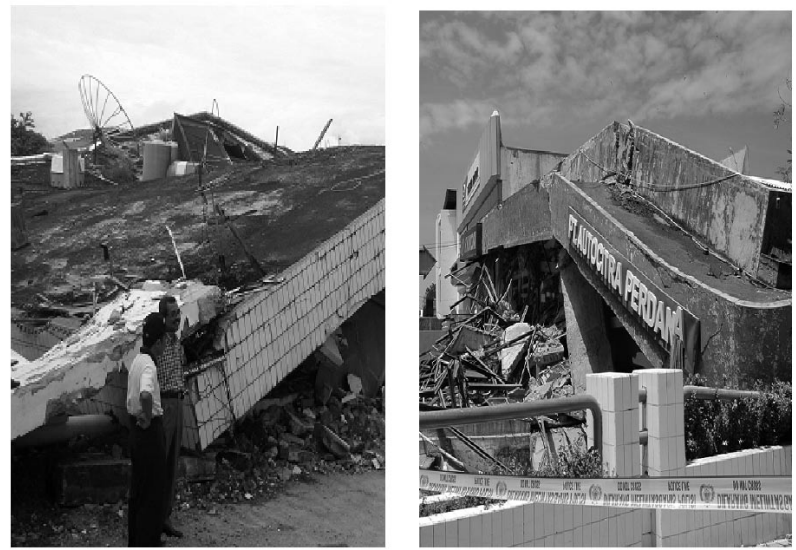

(a) Total Collapse of Three Story Buildings

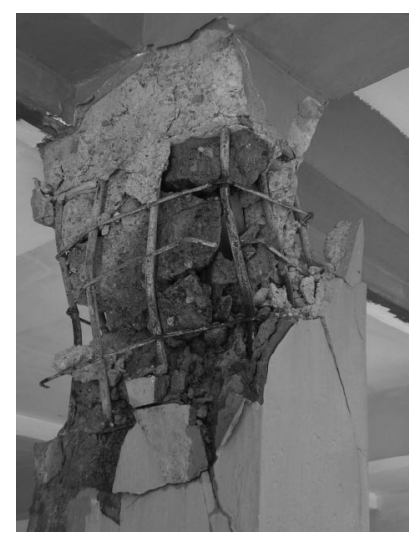

(b) Shear Failure of Column

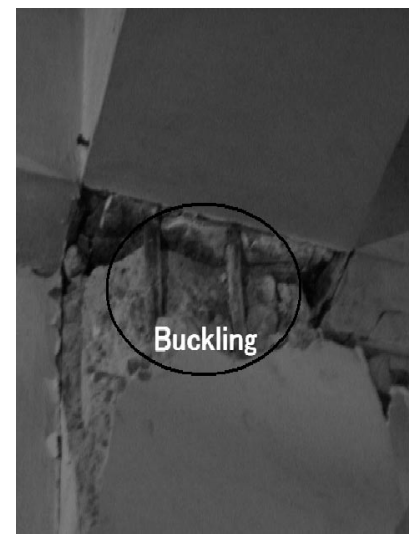

(c) Flexural Failure due to Buckling of Reinforcements

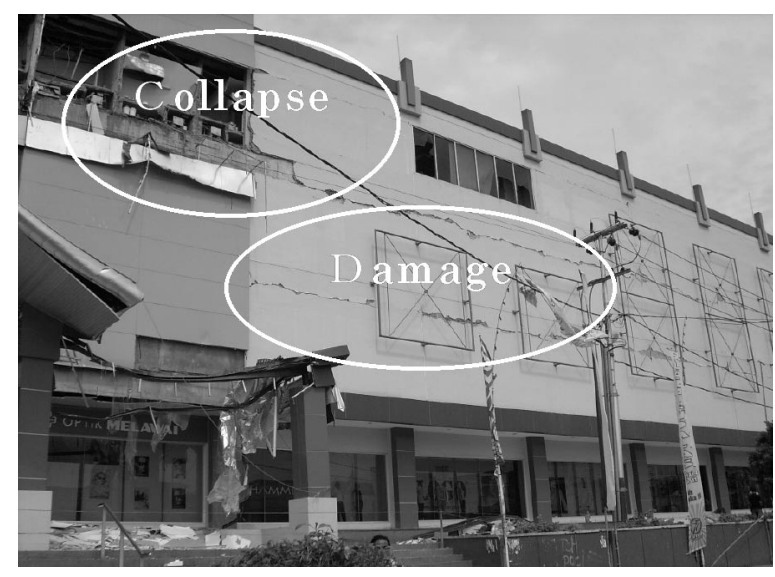

(d) Collapse and Damage of Infill Walls

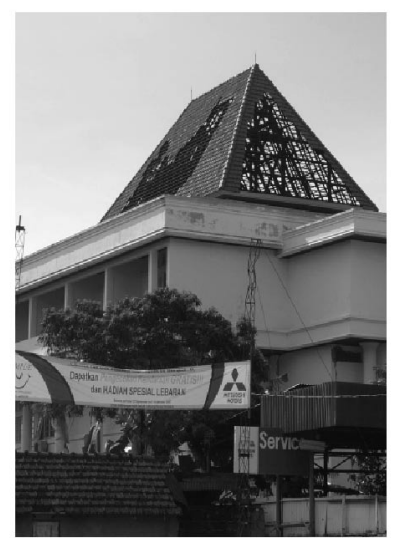

(e) Roof Tiles Fell

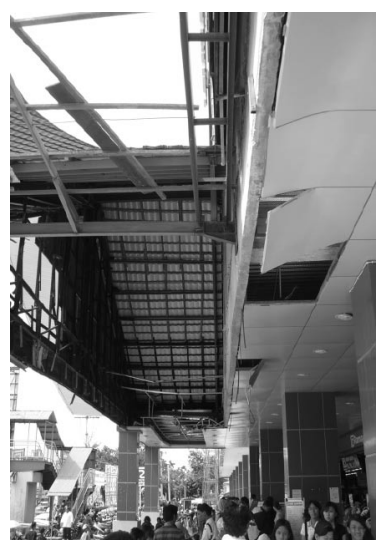

(f) Ceilings Fell

Photo 1. Typical Damage to RC-frame + URM Structures

shown in Photo 1.(a), shear failure of columns as shown in Photo 1.(b), flexural failure of columns due to buckling of longitudinal reinforcements as shown in Photo 1.(c), collapse and/or damage of infill walls as shown in Photo 1.(d), and falling roof tiles and ceilings as shown in Photos 1.(e) and (f). One of the collapsed buildings, shown in Photo 1.(a), was investigated in detail as described in the following section.

The RC-tie + URM type is commonly applied for single-story residences or stores. In this type of building, slender RC columns and beams are provided along the perimeters of masonry walls. Major observed damage was shear cracking of walls. Moreover, this type generally has a corrugated iron roof as shown in Photo 2.(a), which is much lighter than a tile or concrete slab roof. Compared to Javanese residences with clay tile roofing, damaged by the Central Java earthquake, $2006^{3)}$ as shown in Photo 2.(b), light roofing seems to contribute to significantly reducing roof damage.

The URM type consists of brick walls without confinement and a wooden roof truss, which is supported by the walls as shown in Photo 3.(a). This type lacks adequate strength and ductility to resist earthquakes because it often suffers from out-of-plane failure of walls and a resultant total collapse due to roof fall. It is used particularly for residences. Major damage to walls observed during the investigation included complete collapse, shear cracking, separation at corners, and cracking around openings, as shown in Photo 3.

The TIM structure is a traditional residence, as shown in Photo 4. This type of structure usually has

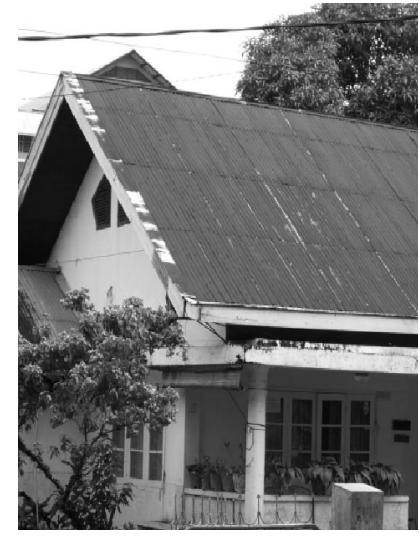

(a) Residence with Corrugated Iron Roofing

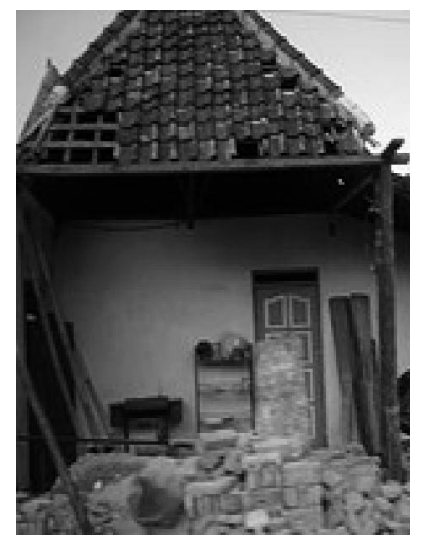

(b) Residence with Tile Roofing Damaged due to the Central Java Earthquake
Photo 2. Comparison of Roofs used in Sumatra and Java Islands 


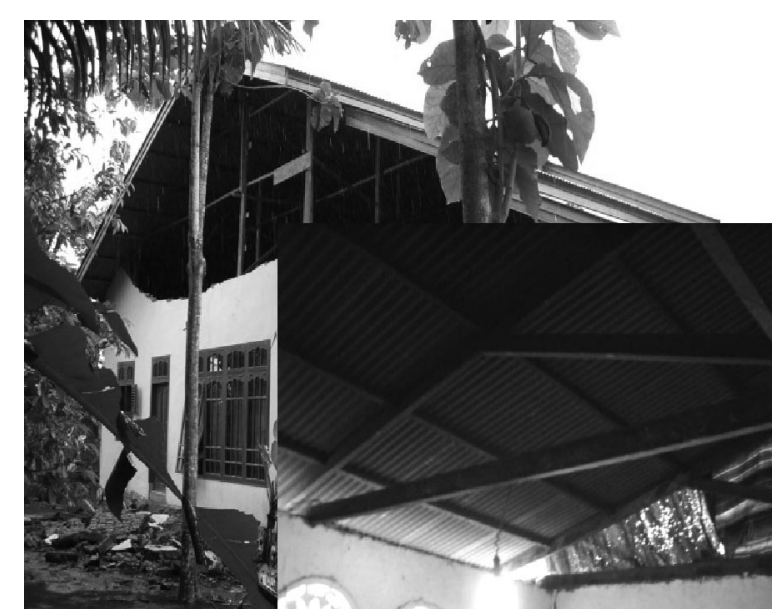

(a) Wooden Roof Truss Supported by Brick Walls

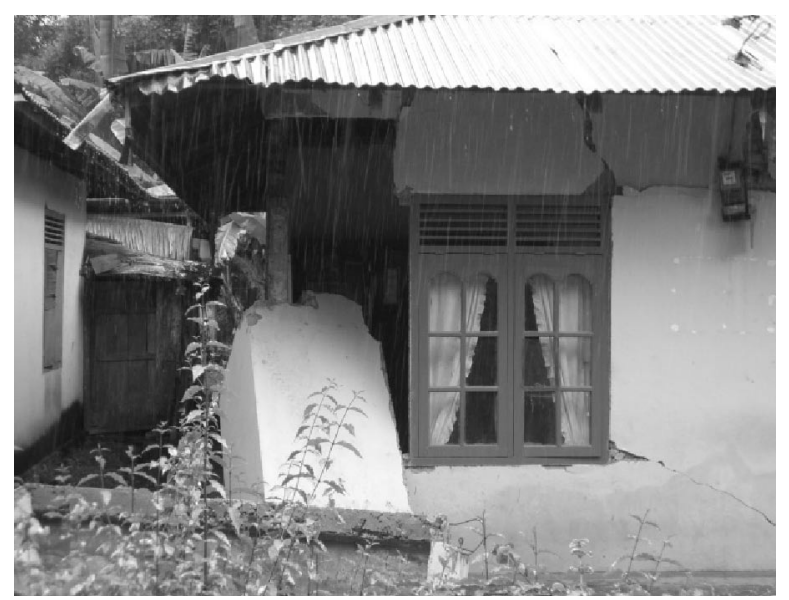

(b) Collapsed Brick Wall and Cracks around the Opening

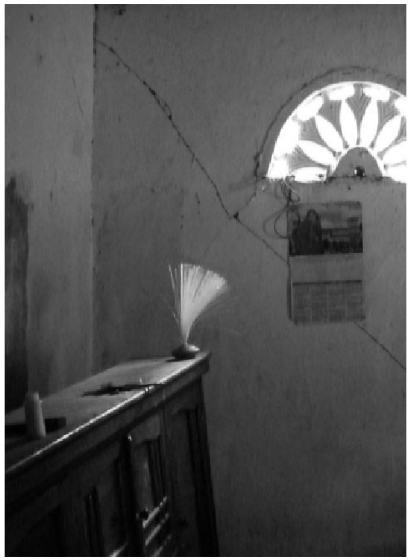

c) Shear Crack on Wall

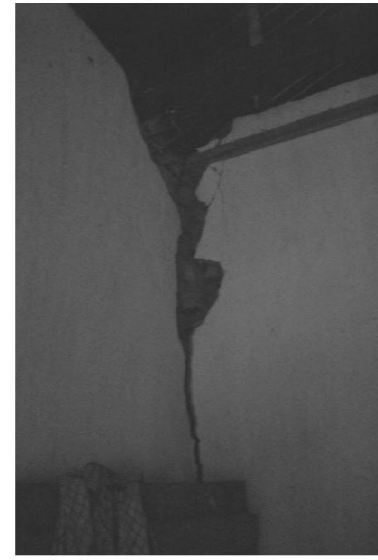
Corner of Walls (d) Separation at the

Photo 3. Typical Damage to URM Structures

a traditional roof called a rumbia roof, which is made from rumbia tree leaves. Almost no damage was observed as shown in the photo. It seems to behave well because of its lightweight materials compared to other building types.

\section{Detailed Investigation of Collapsed Building}

The second stage of the investigation focused on one of the collapsed buildings in Padang, which was

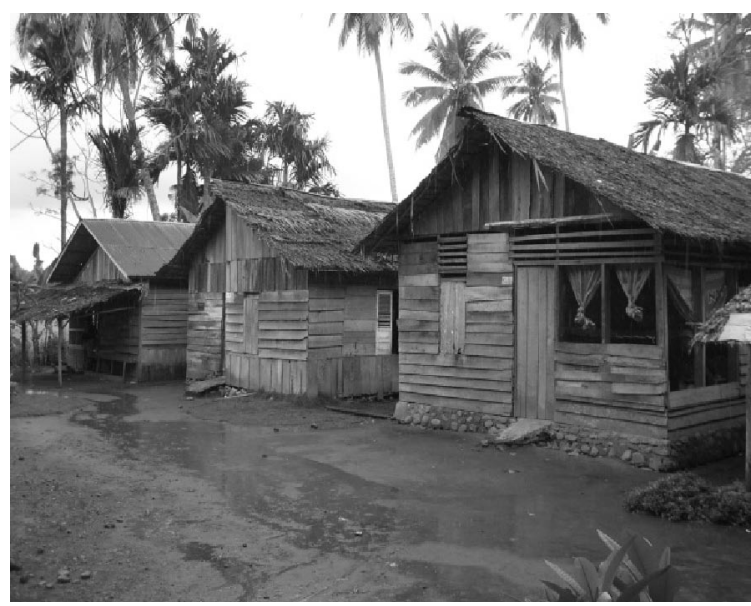

Photo 4. Timber Houses with Rumbia Roofs

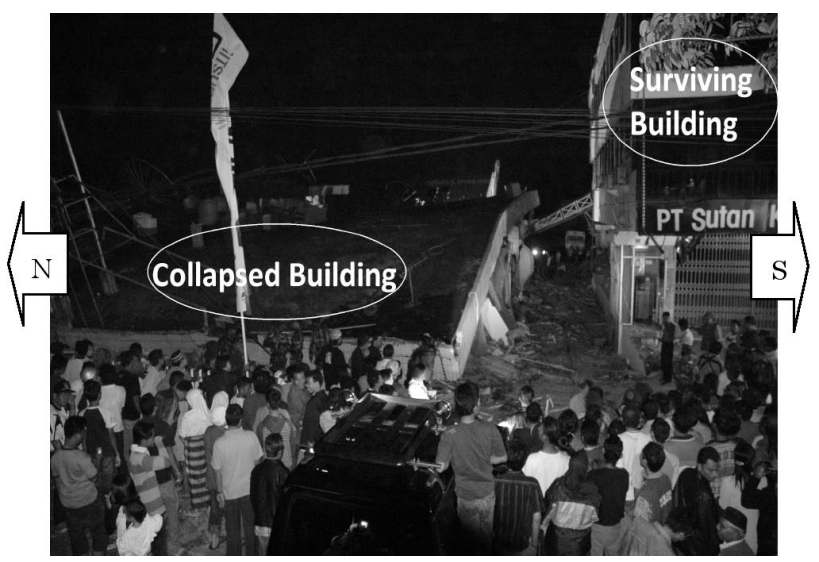

Provided by Padang Ekspres Newspaper

Photo 5. Collapsed and Surviving Buildings just after the Earthquakes

located at the eastern side of Jl. Veteran Damar as shown in Fig.2.(b). A neighboring building survived the earthquakes as shown in Photo 5., nevertheless the structure type was the same as that of the collapsed building. Therefore, a further detailed investigation was conducted to compare damage grades and seismic performance. Structural details of both buildings were collected through on-site inspections and interviews with occupants as well as the owner.

\subsection{Collapsed Building}

The collapsed building was a three-story RC-frame + URM building constructed in 1980, which was used for a car showroom. It was constructed as a two-story building and then the third story was added. Based on photos taken just after the collapse, and information obtained from interviews, this building toppled toward the west, as shown in Photo 5.

This building had a regular plan as illustrated in Fig.3. and Photo 6. As shown, the cross-sectional dimensions of columns were $350 \times 400 \mathrm{~mm}$ for the first story and many spandrel walls were used as exterior walls.

\subsection{Surviving Building}

The surviving building is a three-story RC-frame 


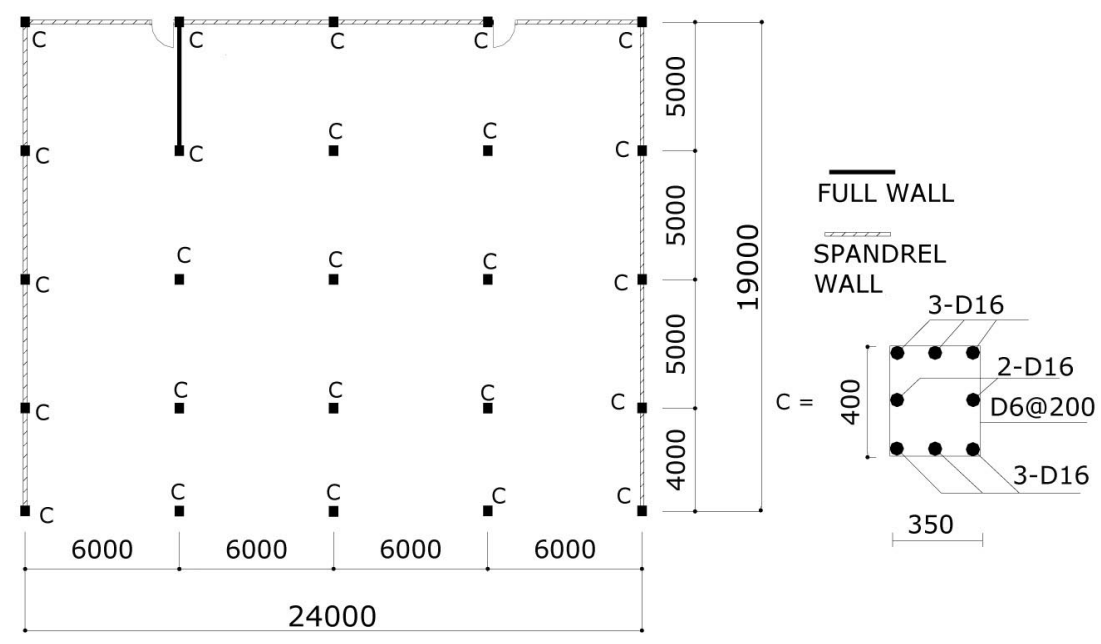

Fig.3. First Floor Plan of Collapsed Building
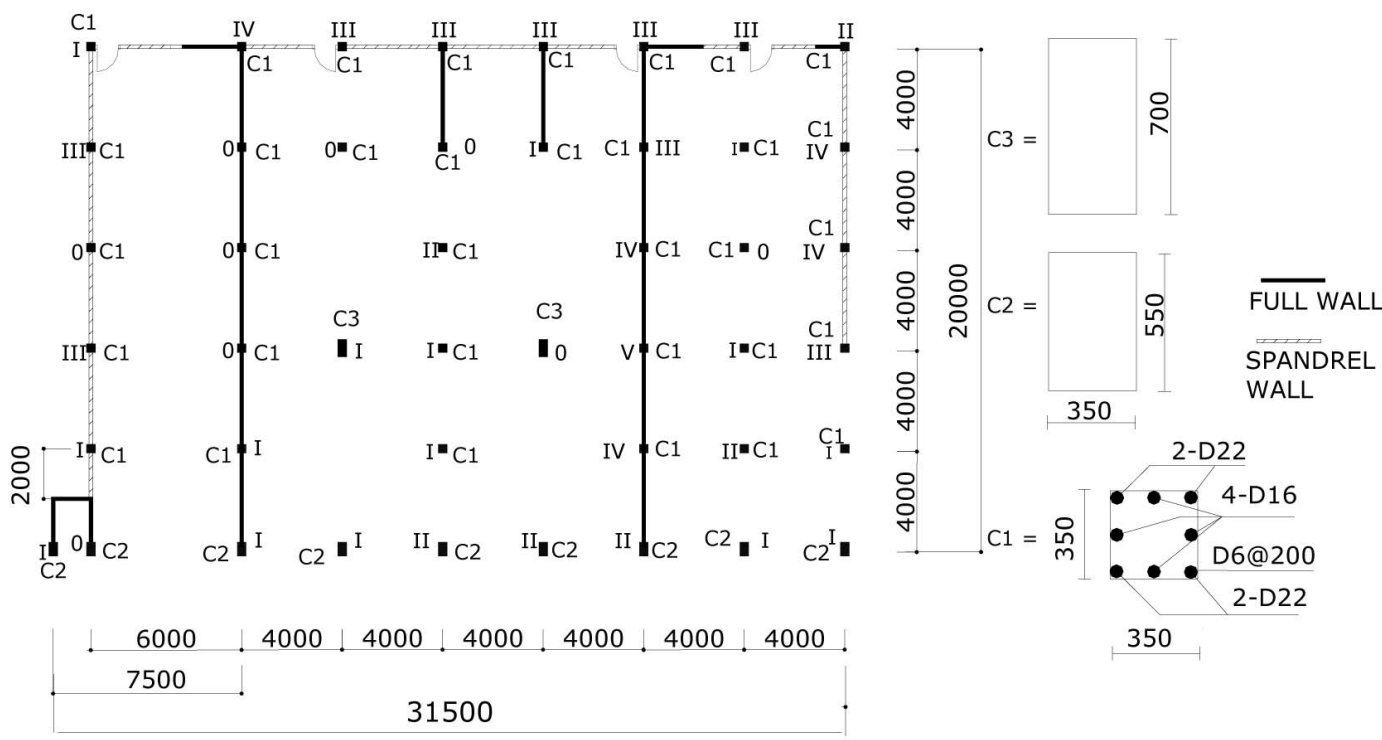

Fig.4. First Floor Plan of Surviving Building and Damage Class of each Column

Table 1. Damage Class Definition of RC Columns ${ }^{4)}$

\begin{tabular}{|c|l|}
\hline Damage Class & \multicolumn{1}{|c|}{ Description of Damage } \\
\hline I & $\begin{array}{l}\text { - Visible narrow cracks on concrete surface } \\
\text { (crack width of less than } 0.2 \mathrm{~mm} \text { ) }\end{array}$ \\
\hline II & $\begin{array}{l}\text { - Visible clear cracks on concrete surface } \\
\text { (crack width of about } 0.2-1.0 \mathrm{~mm} \text { ) }\end{array}$ \\
\hline III & $\begin{array}{l}\text { - Local crushing of concrete cover } \\
\text { - Remarkably wide cracks (crack width of } \\
\text { about 1.0-2.0 mm) }\end{array}$ \\
\hline \multirow{3}{*}{ IV } & $\begin{array}{l}\text { - Remarkable crushing of concrete with } \\
\text { exposed reinforcing bars } \\
\text { - Spalling off concrete cover (crack width } \\
\text { of more than 2.0 mm) }\end{array}$ \\
\hline V & $\begin{array}{l}\text { - Buckling of reinforcing bars } \\
\text { - Cracks in core concrete } \\
\text { - Visible vertical and/or lateral deformation } \\
\text { in columns and/or walls } \\
\text { - Visible settlement and/or leaning of } \\
\text { building }\end{array}$ \\
\hline
\end{tabular}

+ URM building, as shown in Photo 7., which in common with the collapsed building also has a regular plan as illustrated in Fig.4. Details of the building, related to cross-sectional dimensions of structural components, arrangements of reinforcing bars, and damages to columns and walls, were collected to evaluate its damage grade and seismic performance. Damage to the colums was categorized into five classes according to Table 1., based on a reference of Nakano et $\mathrm{al}^{4)}$. The inspection results for the first story are indicated in Fig.4., and several examples of the classified columns are shown in Photo 8. These data were used for evaluating the damage grade of this building also based on the reference 4), which is summarized in Appendix A. As a result, the damage grade was classified as "moderate" for the first story.

\subsection{Relationships between Structural Parameter and Damage Grade}

Table 2. shows several structural parameters for collapsed and surviving buildings with their damage grades. The column and wall ratios (= gross crosssectional area of columns or walls/floor area) of 
Table 2. Structure Parameters and Damage Grades

\begin{tabular}{|c|c|c|c|c|}
\hline \multirow{2}{*}{ Building } & \multirow{2}{*}{$\begin{array}{l}\text { Column } \\
\text { ratio }(\%)\end{array}$} & \multicolumn{2}{|c|}{ Wall ratio $(\%)^{*}$} & \multirow{2}{*}{$\begin{array}{c}\text { Damage } \\
\text { grade }\end{array}$} \\
\hline & & NS & EW & \\
\hline Collapsed & 0.76 & 0.0 & 0.16 & Collapsed \\
\hline Surviving & 1.06 & 0.0 & 1.19 & Moderate \\
\hline
\end{tabular}

both buildings are larger in the case of the surviving building, which is consistent with its lighter damage grade. In these buildings, however, many spandrel walls were used as exterior walls. Because they must have affected structural behavior during the earthquakes, another investigation was conducted as described below.

\subsection{Seismic Performance Evaluation}

Seismic performance of collapsed and surviving buildings was evaluated on the basis of the current Japanese standard ${ }^{5)}$, which is briefly introduced in Appendix B. They were calculated in each direction only for the first story, where the most severe damage was observed to both buildings. In the analyses, however, the reinforcements in $\mathrm{C} 2$ and $\mathrm{C} 3$ columns shown in Fig.4. were assumed to be equivalent to that in $\mathrm{C} 1$ because details of these columns could not be detected. The spandrel walls were considered to evaluate the clear heights of columns. Moreover, although the infill walls were considered as an analytical parameter, wing walls or walls with openings were neglected. Two calculations were conductedone with infills and one without infills. In the case of considering infills, their seismic performance was assumed as shown in Fig.5. based on Reference 6).

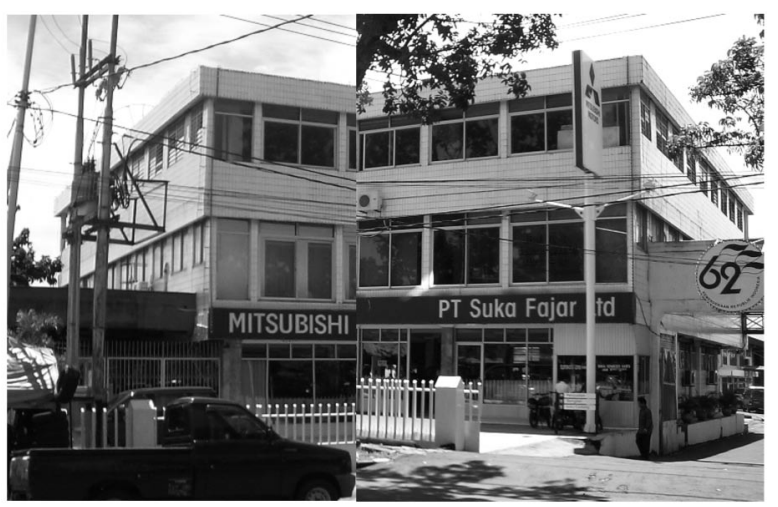

Provided by the owner

(a) Northwest View

(b) Southwest View Photo 6. Collapsed Building

In this study, seismic performance is represented as the relationship between lateral strength index, $C$ and ductility index, $F$ (refer to Appendix B). Fig.6. compares the calculated performance of both buildings. Although the maximum strengths in the E-W direction were higher than those in the N-S direction for both cases, the collapsed building toppled toward the west as already mentioned. Therefore, ground motions were possibly more severe in the E-W direction.

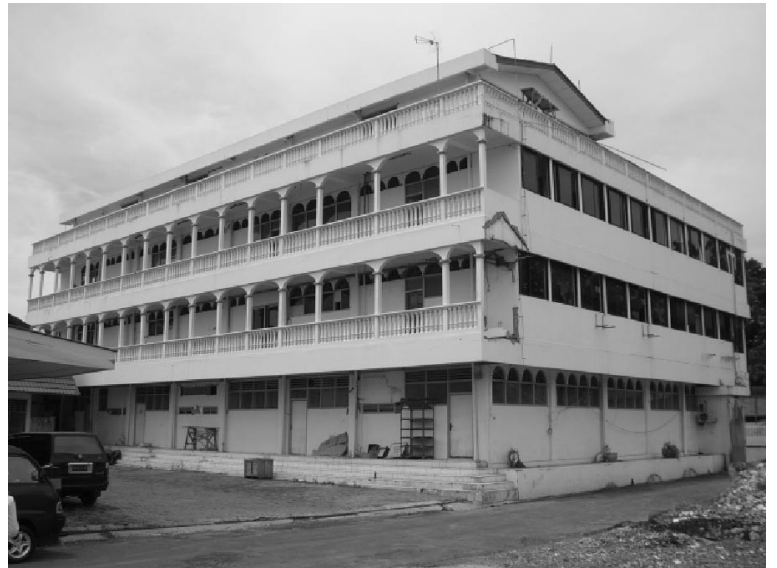

Photo 7. Northeast View of Surviving Building

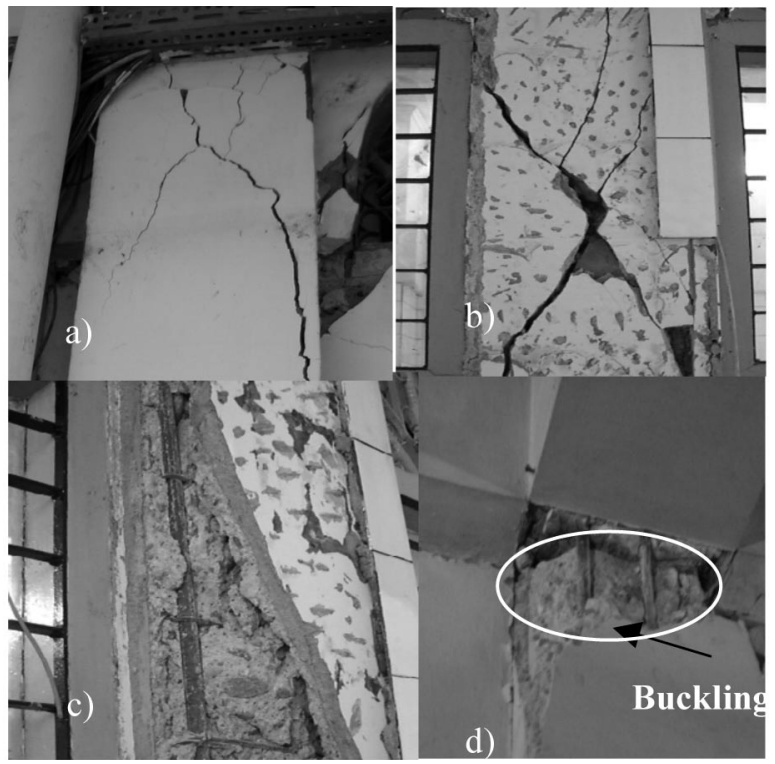

Photo 8. Examples of Classified Columns:

a) Class III: Crack Widths of about 1.0-2.0 mm,

b) Class IV: Crack Widths of more than $2 \mathrm{~mm}$,

c) Class IV: Exposed Reinforcing Bars without Buckling,

d) Class V: Buckling of Longitudinal Reinforcements.

Focusing on the E-W direction, the maximum strength of both buildings was about 0.17 according to the $C$ index, from calculations without infills. These values are relatively low compared to the design strength in Padang. Moreover, although little difference was observed between the maximum strength of the buildings in the case of neglecting the infills, a distinct difference was obtained when considering them. This result indicates that the nonstructural infills significantly contributed to preventing the surviving building from collapsing during the earthquakes.

\section{Conclusions}

Post-earthquake investigation of building structures damaged due to the Sumatra 8.4 and $7.9 \mathrm{M}_{\mathrm{L}}$ earthquakes were carried out in Padang and nearby areas. This paper reports the investigation results, and verifies contributions of nonstructural infill walls to 


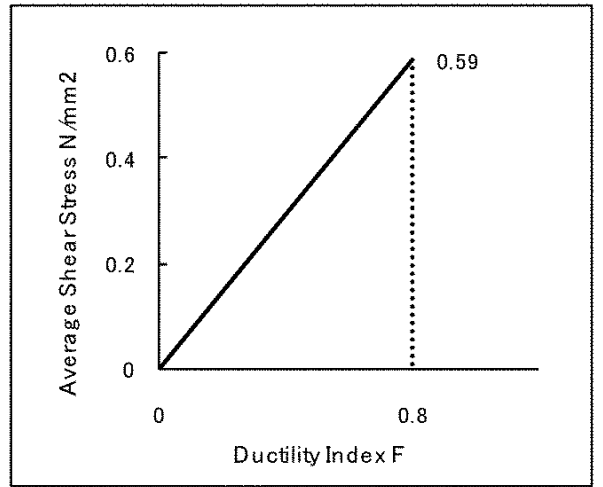

Fig.5. Assumed Seismic Performance of Infills

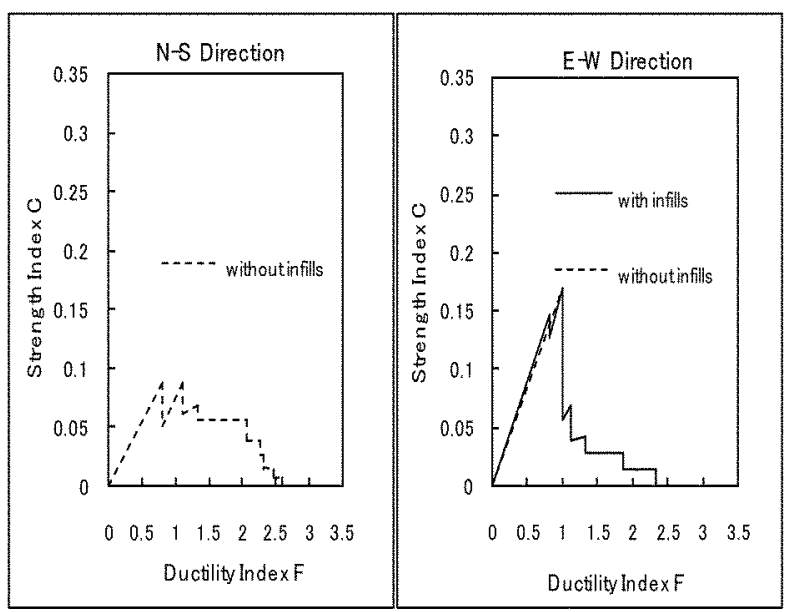

(a) Collapsed Building

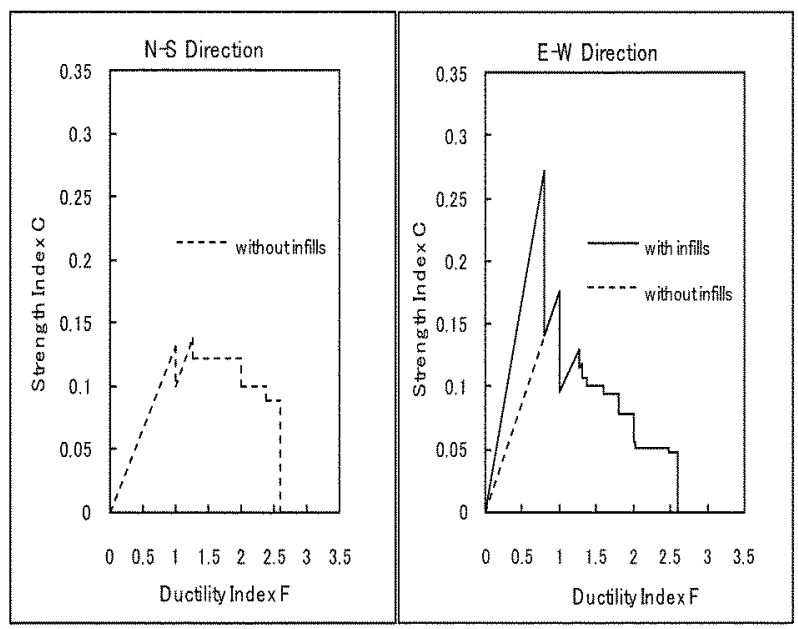

(b) Surviving Building

Fig.6. Comparison of Seismic Performance between the Collapsed and Surviving Buildings

the seismic performance of the earthquake-damaged structures. Major findings are summarized as follows.

1) Two RC frame structures with URM infill walls totally collapsed and many of the same type of building suffered severe damage: shear and flexural failure of columns, collapse and/or damage of infill walls, and falling roof tiles and ceilings.
2) Confined and simple masonry structures also suffered damage. Among these types, however, light roofing seems to have contributed to reducing roof damage.

3) On the contrary, almost no damage was observed in traditional timber structures.

4) One of the collapsed RC frame buildings in Padang was selected for a further detailed investigation. Damage grades and seismic performance of the collapsed building and its neighboring building were briefly evaluated. Differences between damage grades of both buildings could be verified through parametric analyses considering cases with and without infill walls.

5) These samples of earthquake-damaged buildings indicate that nonstructural infill walls can significantly contribute to the seismic performance of this type of structure.

\section{Acknowledgments}

The authors acknowledge Dr. Yukiko Nakamura, Niigata University, Japan for her good collaboration in our observation and we thank Dr. Jafril Tanjung, Andalas University, Indonesia for his guidance during the survey. We are also grateful to owners and occupants of investigated buildings for offering information. Several materials in this paper were provided by USGS and Padang Ekspres newspaper.

\section{References}

1) USGS Website: http://earthquake.usgs.gov/.

2) The National Disaster Management Coordinating Board of Indonesia (BAKORNAS): http://bakornaspb.go.id/website (in Indonesian).

3) Architectural Institute of Japan (AIJ). (2007) Report on the Damage Investigation of the 2006 Central Java earthquake.

4) Yoshiaki NAKANO, Masaki MAEDA, and Hiroshi KURAMOTO. (2004) Guideline for Post Earthquake Damage Evaluation and Rehabilitation of RC Buildings in Japan. $13^{\text {th }}$ World Conference on Earthquake Engineering, Vancouver, B.C., Canada.

5) The Japan Building Disaster Prevention Association. (2005) English Version, $1^{\text {st }}$, Standard for Seismic Evaluation of Existing Reinforced Concrete Buildings, 2001.

6) Architectural Institute of Japan (AIJ). (2000) Report on the Technical Cooperation for Temporary Restoration of Damaged RC School Buildings due to the 1999 Chi-Chi Earthquake (in Japanese).

\section{Appendix A}

In this study, the damage grade was determined according to the residual capacity index, $R$, calculated by Eq. 1 in Reference 4).

$$
R=\frac{\sum_{j=0}^{5} \eta_{j} A_{j}}{A_{\text {org }}}
$$

where, $A_{j}$ : total number of columns having damage class 0 through $\mathrm{V}, A_{\text {org }}$ : total number of investigated columns, $\eta_{j}$ : seismic capacity reduction factor from Table 3. 
Table 3. Seismic Capacity Reduction Factor $\eta$

\begin{tabular}{|c|c|c|}
\hline Damage class & Brittle column* & Ductile column* \\
\hline I & 0.95 & 0.95 \\
\hline II & 0.60 & 0.75 \\
\hline III & 0.30 & 0.50 \\
\hline IV & 0 & 0.10 \\
\hline V & 0 & 0 \\
\hline * Brittle column: $h_{0} / D \leq 3$, Ductile column: $h_{0} / D>3$, \\
where, $h_{0}$ : column clear height, $D$ : column depth. \\
\hline
\end{tabular}

The damage grade of a building is defined according to the following classification based on $R$ value.

Slight damage: $\quad 95 \% \leq \mathrm{R}$

Light damage: $\quad 80 \% \leq \mathrm{R}<95 \%$

Moderate damage: $\quad 60 \% \leq \mathrm{R}<80 \%$

Heavy damage: $\quad \mathrm{R}<60 \%$

Collapse: $\quad \mathrm{R} \approx 0$

\section{Appendix B}

Seismic performance of investigated building was evaluated as a $C-F$ relationship based on Reference 5). The cumulative strength index, $C$ at a certain ductility index, $F$ was calculated by Eq. 2 .

$$
\begin{aligned}
& C=C_{i}+\sum_{j} \alpha_{j} C_{j} \\
& C_{i}=Q_{u i} / \sum W
\end{aligned}
$$

where, $C_{i}$ : strength index of the $i$-th group of vertical members having the same ductility index, calculated using Eq. 3, $C_{j}$ : strength index of the $j$-th group having the same ductility index larger than that of $i$-th group, $\alpha_{j}$ : effective strength factor (reduction factor) of the $j$-th group for considering differences between yield deformations of $i$ - and $j$-th groups, $Q_{u i}$ : ultimate lateral load-carrying capacity of the $i$-th group of vertical members, $\Sigma W$ : total weight of building supported by the story concerned.

The ductility index, $F$ represents deformability of certain vertical members calculated according to structural specifications: member type, failure mode, strength, dimension, etc. This index for columns, excepting extremely short ones, ranges between 1.0 and 3.2, which corresponds to a lateral drift ratio of $1 / 250$ and $1 / 30$, respectively. 